\title{
The development of students' achievement emotions after transition to secondary school: a multilevel growth curve modelling approach
}

\author{
Simon Meyer ${ }^{1}$ (D) $\cdot$ Juliane Schlesier $^{2}$ (D)
}

Received: 11 May 2020 / Revised: 9 December 2020 / Accepted: 11 January 2021 / Published online: 18 April 2021

(C) The Author(s) 2021

\begin{abstract}
This empirical study focuses on students' development of positive and negative achievement emotions during the first year and the beginning of the second year of secondary school. Using multilevel growth curve modelling, the development of the achievement emotions enjoyment, pride, anxiety, hopelessness and boredom during class in general was investigated. Data from 584 students (taken at three different time points during the first year and the beginning of the second year of secondary school in Germany) was analysed by controlling for gender and the type of school. The results confirm the main assumption: positive achievement emotions decline, whereas negative achievement emotions increase after transition to secondary school. The assumption regarding the effects of type of school was also confirmed: students entering a higher track school (German Gymnasium) experience more positive achievement emotions than students in middle track schools (German Realschule) do. However, the decline in these achievement emotions in higher track schools is comparatively worse than for students in middle track schools. The results are discussed with regard to students' further studies, as well as the wider educational implications.
\end{abstract}

Keywords Achievement emotions · Secondary school $\cdot$ Transition $\cdot$ Multilevel growth curve modelling

Simon Meyer

simon.meyer@fau.de

Juliane Schlesier

juliane.schlesier1@uni-oldenburg.de

1 Faculty of Humanities, Social Sciences, and Theology, Research and Teaching Unit School Education and Instructional Research, Friedrich-Alexander-University of Erlangen-Nuremberg, Regensburger Straße 160, 90478 Nuremberg, Germany

2 Department of Empirical Research on Learning and Instruction/Department of Educational Psychology, Institute of Educational Sciences, Carl von Ossietzky University Oldenburg, Box 2503, 26111 Oldenburg, Germany 


\section{Introduction}

Traditionally, research on learning and instruction has focused mainly on cognitive factors, while non-cognitive aspects, such as achievement emotions, have generally been neglected (Pekrun 2016). In the last 20 years, however, achievement emotions of pride, enjoyment, hope, anxiety, shame, anger or boredom have received more attention (Pekrun and LinnenbrinkGarcia 2014). Today it is widely acknowledged that students' achievement emotions are important for learning and achievement in school. Students who experience positive achievement emotions show a higher level of well-being (Hascher 2007), apply more effective learning strategies that lead to better cognitive performance (Linnenbrink 2007), are often intrinsically motivated (Meyer and Gläser-Zikuda 2020; Deci and Ryan 2002), and demonstrate higher levels of school achievement (Goetz et al. 2008; Pekrun and Perry 2014).

Emotions in a school environment are particularly important in the context of transition processes (Dias and Sá 2014; van Ophuysen 2009). The transition from primary to secondary school is associated with changes that affect organisational aspects (e.g. the course system and a higher number of students and classes), social aspects (e.g. new classmates) and educational aspects (e.g. less self-directed learning and autonomy) that may be related to an increase in negative achievement emotions and stress (Becker et al. 2014; Dias and Sá 2014). Therefore, the transition to secondary school is often conceptualised as a normative critical life event (Filipp 2001).

This study focuses on the development of positive (enjoyment and pride) and negative (anxiety, hopelessness and boredom) achievement emotions in class in general during the first year and the beginning of the second year of secondary school and considers the structure of the hierarchically nested data by using multilevel growth curve models. The five examined discrete achievement emotions are important during major educational transitions, especially in the context of the transition from primary school and in the further course of the first years of secondary school.

\section{Achievement emotions: theoretical background}

Emotions are generally defined as multicomponent phenomena involving coordinated psychological processes that, according to Frenzel et al. (2015) and Scherer (2009), include affective components (e.g. a nervous feeling in the case of anxiety); cognitive components (worries); physiological components (increased cardiovascular activity); expressive components (nervous facial expressions); and motivational components (avoidance motivation or impulses to escape from a situation).

According to Pekrun's (2006) taxonomy, achievement emotions can be classified as those being directly related to achievement activities (activity emotions) or achievement outcomes (outcome emotions). Activity emotions are experienced during learning (e.g. enjoyment or boredom), while outcome emotions (e.g. hope, pride, anxiety or shame) are experienced in connection with success or failure (Pekrun 2017). Achievement emotions can also be categorised by their valence (negative vs. positive) and their degree of activation (deactivating vs. activating) (Pekrun 2006, 2017).

In the context of the development of achievement emotions, the control-value theory of achievement emotions (Pekrun 2006) provides an integrative approach for the mutual precursors and effects of emotions experienced in achievement and academic settings (Pekrun 2006; 
Pekrun and Perry 2014). The theory assumes that two factors are relevant for the development of achievement emotions: subjective control over achievement emotions and outcomes, and the subjective values of these activities and outcomes (Pekrun 2006; Pekrun and Perry 2014). Similar to the control-value theory, the stage-environment fit theory (Eccles and Midgley 1989) offers an approach to explain the reasons for the increase or the decline of positive and negative achievement emotions in class. Based on this theory, the possible decline in positive motivational factors (e.g. self-concept, learning motivation) during secondary school, which according to the control-value theory has a significant influence on the development of achievement emotions, may be explained by a discrepancy between contextual conditions in school and the developmental needs of students of that age group. More teacher-oriented teaching, increasing performance demands, and the declining quality of social interactions may have negative effects on students' learning, motivation and self-concept - and thus on their positive and negative achievement emotions (Deci and Ryan 2002; Pekrun et al. 2017; Pekrun et al. 2018; Symonds and Hargreaves 2016).

\section{Longitudinal studies on the development of achievement emotions}

Over the last two decades, several studies have examined the development of achievement emotions during adolescence in a school context (e.g. Hagenauer and Hascher 2010; Pekrun et al. 2007; Vierhaus et al. 2016). Most studies refer to achievement emotions experienced during secondary school, with an emphasis on the development of achievement emotions of enjoyment or anxiety; however, empirical evidence on the development of negative achievement emotions of hopelessness or boredom at school is still rather limited (Pekrun et al. 2010; Pekrun et al. 2018). Furthermore, there is a lack of studies that investigate systematic changes in the development of achievement emotions using multilevel growth curve modelling.

Moreover, research on achievement emotions in primary schools has been rather neglected. Regarding positive achievement emotions in primary school, Helmke (1993) reports a continuous decline from kindergarten to the fifth grade in German and mathematics (see also Gentry et al. 2002). In line with these results, Lichtenfeld et al. (2012) reveal a decline of enjoyment from the second to the third grade. However, Vierhaus et al. (2016) report that enjoyment at school tends to remain stable during the primary school years. In contrast to the levels of enjoyment, the negative achievement emotions of anxiety and boredom increase slightly during primary school (Lichtenfeld et al. 2012; Zeidner 2014). Nevertheless, the level of positive achievement emotions at the end of primary school exceeds the level of negative achievement emotions (Raccanello et al. 2013).

Several studies confirm quite high levels of positive achievement emotions after the transition to secondary school (Bieg et al. 2019; Gentry et al. 2002; Pekrun et al. 2007; Vierhaus et al. 2016), which could be explained by positive expectations and anticipation on the part of the students (van Ophuysen 2009). With regard to further emotional development in the first year of secondary school, studies show a relatively negative trend in some emotions: the positive achievement emotions of enjoyment and pride decrease (Gentry et al. 2002; Pekrun et al. 2007; Vierhaus et al. 2016) while the negative achievement emotions of anger, hopelessness and boredom increase (Pekrun et al. 2007).

Regarding the development of positive achievement emotions from the sixth to the ninth grade, several studies indicate a further decline of enjoyment (Bieg et al. 2019; Buff 2014; Hagenauer and Hascher 2010; Raccanello et al. 2013; Vierhaus et al. 2016) and pride (Goetz 
et al. 2012; Raccanello et al. 2013). The "Project for the Analysis of Learning and Achievement in Mathematics" (PALMA - see Pekrun et al. 2007) is a domain-specific longitudinal study that examined the development of students' performance in mathematics; it shows that positive achievement emotions decrease significantly from the fifth grade to the ninth grade. The decline of the positive achievement emotions of enjoyment and pride is especially significant in the first two years of secondary school (Pekrun et al. 2007).

Regarding negative achievement emotions in the later course of secondary school, studies have found a growth in the negative achievement emotions of anger, boredom, anxiety and hopelessness (Ahmed et al. 2013; Bieg et al. 2019; Raccanello et al. 2013; Vierhaus et al. 2016). The findings of PALMA (Pekrun et al. 2007) indicate that the negative achievement emotions of anger, hopelessness and boredom increase significantly, while feelings of anxiety and shame related to mathematics remain quite stable. However, there is an asymptotic relationship, which means that the changes become progressively smaller over the years (Pekrun et al. 2007). With regard to the achievement emotion of boredom, Goetz et al. (2006) point out that the increase is due mainly to aspects of classroom management and depends on the respective subject (see also Gläser-Zikuda et al. 2005).

Several studies have analysed the relationship between emotions and students' school achievement. In particular, negative emotions such as test anxiety show correlations with lower school achievement, while positive emotions - due to higher motivation-correlate with higher achievement (Goetz and Hall 2013; Mega et al. 2014; Pekrun et al. 2017).

\section{Effects of gender}

In terms of gender, several studies confirm that it strongly influences the development of students' achievement emotions during secondary school. Regarding development of the positive achievement emotion of enjoyment in the classroom in general, Gentry et al. (2002) report consistently higher levels of enjoyment for girls during secondary school than for boys (see also Eder 2007). Concerning the negative achievement emotion of boredom, Daniels et al. (2009) point out that boys report more boredom in the first year of secondary school than girls do. However, gender differences in achievement emotions are related to the different subjects. In mathematics in particular, boys perceive less negative and more positive achievement emotions than girls do (Goetz et al. 2013; Pekrun et al. 2010; Pekrun et al. 2017).

\section{Effects of the type of school}

With regard to effects of the type of school, the assessment of the own abilities (frame of reference effect-Marsh and Hau 2003) is particularly important. In this context, van Ophuysen $(2008,2009)$ notes that the development of enjoyment decreases more steeply at the higher track schools (German Gymnasium), where students start with higher values of enjoyment than students entering middle track schools (German Haupt-/Mittelschule or Realschule) (see also Harazd and Schürer 2006). Although students who attend lower or middle track schools start with a lower level of enjoyment, the subsequent further decrease is not as significant as in the higher track schools (see big-fish-little-pond effect: equally capable students have higher academic self-concepts in low-ability groups than in high-ability groups-Marsh and Parker 1984; Marsh et al. 2007). Notably, Valtin and Wagner (2004) 
report an opposite trend in the development of the achievement emotion anxiety in the first year after transition to secondary school (see also Knoppick et al., 2015; Zeidner and Schleyer 1999). Goetz et al. (2004) examined domain-specific differences in the development of achievement emotions and report a stronger increase of the achievement emotion of anxiety from the fifth to the sixth grade among students from higher track schools (see also Eder 2007). Overall, it can be seen that the development of achievement emotions of students entering a high-achievement learning environment tends to be more negative during the first years in secondary school.

To sum up, several studies in this context point to a rather negative trend in achievement emotions during the course of secondary school. The significant decline in some positive achievement emotions and the increase in some negative achievement emotions directly after the transition to secondary school highlights the crucial importance of this transition in students' educational careers. Thus, it continues to be an important topic for further research. Apart from the fact that the exact extent of the development of these emotions is not outlined yet, the role of gender and the type of school regarding the development of these emotions is still not completely researched.

\section{The present research study}

This study focuses on the analysis of systematic changes in the development of positive and negative achievement emotions in children, in the period after the transition to secondary school. In view of the fact that achievement emotions seem to change particularly after the transition to secondary school (Dias and Sá 2014), it is important to investigate this period, which is described as a normative critical life event (Filipp 2001).

Hence, this study pursues four aims: our first research question investigates how the positive achievement emotions of enjoyment and pride develop in the first year and the beginning of the second year after transition to secondary school. Following the findings of previous research based on the stage-environment fit theory (Eccles and Midgley 1989) and the control-value approach (Pekrun 2006), we expect a decline in enjoyment and pride in the first year of secondary school (Gentry et al. 2002; Pekrun et al. 2007; Vierhaus et al. 2016) (Hypothesis 1).

The second research question relates to the development of the negative achievement emotions of anxiety, hopelessness and boredom. In view of previous findings (Bieg et al. 2019; Pekrun et al. 2007; Raccanello et al. 2013; Vierhaus et al. 2016), we expect a continuous increase in negative achievement emotions during the first year of secondary school (Hypothesis 2).

Our third research question addresses the development of positive and negative achievement emotions with regard to the type of school. Based on previous research (Harazd and Schürer 2006; van Ophuysen 2008, 2009), we assume higher values of positive achievement emotions among students from higher track schools, but with a greater rate of decline of these achievement emotions during the first year of secondary school, compared to students from middle track schools. With regard to negative achievement emotions, we expect a stronger increase from the fifth to the sixth grade among students from higher track schools (Goetz et al. 2004; Valtin and Wagner 2004) (Hypothesis 3).

The fourth research question focuses on gender effects regarding the development of positive and negative achievement emotions during the first year and the beginning of the second year of secondary school. Based on previous research concerning gender effects in 
school in general (Daniels et al. 2009; Gentry et al. 2002), we expect that boys experience more negative and fewer positive achievement emotions than girls do (Hypothesis 4).

\section{Method}

\section{Participants and design}

The sample consisted of 584 German secondary school students $\left(M_{\text {age }}=10.19\right.$ years, $S D=$ $0.45,84.9 \%$ female). The students attended 52 classes in 23 private schools under ecclesiastical sponsorship in southern Germany, where students entering a type of school within the tripartite school system including lower track schools (German Mittelschule), middle track schools (German Realschule) and higher track schools (German Gymnasium) after four years in primary school. These three types of school differ mainly in students' entry level of academic ability and academic requirements. The sample comprised students from two types of schools within the German secondary school system, namely middle track schools $(56.2 \%)$ and higher track schools (43.8\%).

Regarding place of birth, the majority of students reported that they and their parents were born in Germany (74.9\%), and 21\% reported that at least one parent was not born in Germany. The percentage of students not born in Germany was $4.1 \%$.

The students participated in the survey during their regular class time and completed online questionnaires using school computers. The survey began in October 2017 (t1), six weeks after students entered the fifth grade (first year of secondary school), and was repeated in April/June 2018 (t2) and October 2018 (t3; second year of secondary school). The survey was part of an evaluation project.

\section{Measures of achievement emotions}

The achievement emotions of enjoyment, pride, anxiety, hopelessness and boredom were assessed using the Achievement Emotions Questionnaire-Mathematics (AEQ-M - see Pekrun et al. 2005) with a Likert-type scale from 1 (strongly disagree) to 5 (strongly agree). The items were adapted for this study to focus on how the students feel during class in general, doing their homework, or writing a test. The instrument includes five scales that measure the five achievement emotions: enjoyment (10 items; e.g. "I enjoy my class."), pride (6 items; e.g. "After a test I am proud of myself."), anxiety (15 items; e.g. "I worry if this is all too difficult for me."), hopelessness (6 items; e.g. "During the test I feel hopeless.") and boredom (6 items; e.g. "My homework bores me to death.") (Cronbach's $\alpha$ ranges between .85 and .90). Previous studies related to the AEQ indicate that the scales are internally valid, as confirmed by confirmatory factor analysis (e.g. Frenzel et al. 2007; Pekrun et al. 2007; Pekrun et al. 2011; Pekrun et al. 2017).

\section{Statistical analyses}

In order to gain insight into the longitudinal data, a repeated measures analysis of variances (ANOVA, with time as the sole predictor, using three time points) was executed for the achievement emotions of enjoyment, pride, anxiety, hopelessness and boredom using RStudio (version 1.3.1056). The data was first transformed into a long format using the reshape() 
function (package stats, version 3.4.3). The ANOVA was then conducted using the ez-package (version 4.4-0). Fisher's least significant difference (FLSD) was subsequently calculated in order to determine which means of the three time points differ significantly.

Using the R package nlme (version 1.1-21), the longitudinal data was then analysed using multilevel growth curve modelling to enhance the results from the ANOVA. The calculation of the multilevel growth curve modelling aims to adjust a development trajectory based on longitudinal data, since it involves the analyses of repeated measurements of a manifest variable at three or more time points (Vierhaus et al. 2016).

To explore the development of the variables, a baseline model (Model 1) was fitted using a $g l s($ function, which contained only the intercept (Field et al. 2012). The fit of Model 1 was estimated using the maximum likelihood method.

Then, using the lme() function, a random intercept model (Model 2) was calculated, which included the varying of intercepts across people (Field et al. 2012). The model equations (see Hosoya et al. 2014) for the unconditional random intercept model without time as a predictor are as follows:

\begin{tabular}{ll}
\hline$y_{t i}=\beta_{0 i}+\varepsilon_{t i}$ & Level 1 equation \\
$\beta_{0 i}=\gamma_{00}+v_{0 i}$ & Level 2 equation \\
$y_{t i}=\gamma_{00}+v_{0 i}+\varepsilon_{t i}$ & general equation \\
\hline
\end{tabular}

where $y_{t i}$ represents the outcome variable (e.g. enjoyment), $\beta_{0 i}$ is the varying intercept and $\varepsilon_{t i}$ the residual variance. $\gamma_{00}$ represents the intercept (global effect) and $v_{0 i}$ the person-specific variability in intercepts.

Next, time was included as a predictor. The model equations for the unconditional random intercept model with time as a predictor (Model 3) are described in the following:

\begin{tabular}{ll}
\hline$y_{t i}=\beta_{0 i}+\beta_{1 i} x_{1 t i}+\varepsilon_{t i}, \beta_{0 i}=\gamma_{00}+v_{0 i}$ & Level 1 equation \\
$\beta_{1 i}=\gamma_{10}$ & Level 2 equations \\
$y_{t i}=\left(\gamma_{00}+v_{0 i}\right)+\gamma_{10} x_{1 t i}+\varepsilon_{t i}$ & general equation, \\
\hline
\end{tabular}

where $x_{1 t i}$ represents the time-varying predictor, $\beta_{1 i}$ the slope and $\gamma_{10}$ the average rate of change.

Following that, in Model 4, the intercepts and the effect of time were varied across participants (random intercept random slope model). The model equations for Model 4 are as follows:

\begin{tabular}{ll}
\hline$y_{t i}=\beta_{0 i}+\beta_{1 i} x_{1 t i}+\varepsilon_{t i,} \beta_{0 i}=\gamma_{00}+v_{0 i}$ & Level 1 equation \\
$\beta_{1 i}=\gamma_{10}+v_{1 i}$ & Level 2 equations \\
$y_{t i}=\left(\gamma_{00}+v_{0 i}\right)+\left(\gamma_{10}+v_{1 i}\right) x_{1 t i}+\varepsilon_{t i}$ & general equation, \\
\hline
\end{tabular}

where $v_{1 i}$ represents the level-2 residual variance.

In the unconditional full model (Model 5), gender and the type of school were included as predictors on level 2. The whole procedure was processed for linear growth development. The model equations for the full model are described in the following:

\begin{tabular}{ll}
\hline$y_{t i}=\beta_{0 i}+\beta_{1 i} x_{1 t i}+\varepsilon_{t i,} \beta_{0 i}=\gamma_{00}+\gamma_{01} z_{1 i}+v_{0 i}$ & Level 1 equation \\
$\beta_{1 i}=\gamma_{10}+\gamma_{11} z_{1 i}+v_{1 i}$ & Level 2 equations \\
$y_{t i}=\left(\gamma_{00}+v_{0 i}\right)+\gamma_{01} z_{1 i}+\left(\gamma_{10}+v_{1 i}\right) x_{1 t i}+\gamma_{11} z_{1 i} x_{1 t i}+\varepsilon_{t i}$ & general equation, \\
\hline
\end{tabular}

where $z_{1}$ represents a level-2 predictor and $\gamma_{11}$ represents how the effect of time $\left(x_{1 t i}\right)$ on the outcome variable (e.g. enjoyment) is moderated by a level-2 predictor $z_{1}$ (e.g. gender). 


\section{Results}

\section{Descriptive statistics}

The results of the ANOVA and FLSD reveal that the positive achievement emotions of enjoyment and pride decreased significantly, whereas the negative achievement emotions of anxiety, hopelessness and boredom increased significantly (see Table 1). The effects are significant for all achievement emotions for all time points, with the exception of pride. The effect sizes range between 0.004 and 0.05 .

\section{Multilevel growth curve models of achievement emotions}

The results of the multilevel growth curve model for the positive achievement emotion of enjoyment (see Table 2) show that the addition of a random intercept (Model 2) significantly improved the fit of the model $\left(\chi^{2}(3)=337.42, p<.001\right)$. Analogously, adding the fixed effect of time (Model 3 ) significantly improved the model fit $\left(\chi^{2}(4)=216.56, p<.001\right)$. Compared to Model 3, adding a random slope for the effect of time across students (Model 4) significantly improved the model fit as well $\left(\chi^{2}(6)=21.94, p<.001\right)$. However, the full model including all predictors (Model 5) did not significantly improve the fit. Concerning changes in the positive achievement emotion of enjoyment during the first year and the beginning of the second year of secondary school, the models reveal that the effect of time $(\beta=-0.19(-0.21$, $-0.16), t(1167)=-14.13, p<.001)$ is highly significant, which indicates that enjoyment changes significantly. Furthermore, the standard deviation of intercepts is $0.58(0.51,0.65)$, and of slopes (the effect of time across students) is $0.18(0.14,0.22)$. Moreover, Model 5 shows that the type of school has a small but significant effect on the development of enjoyment $(\beta=0.11(0.03,0.19), t(581)=2.75, p<.05)$ : students from higher track schools experience more enjoyment than students from middle track schools. With regard to gender effects, there is also a small but significant impact: girls feel significantly more enjoyment than boys do in the course of the first year and the beginning of the second year of secondary school $(\beta=-0.13(-0.24,-0.01), t(581)=-2.22, p<.05)$.

Concerning the positive achievement emotion of pride, the results in Table 3 show that adding a random intercept (Model 2) significantly improved the model fit $\left(\chi^{2}(3)=478.85, p<.001\right)$. Similarly, adding the fixed effect of time (Model 3$)$ significantly improved the model fit $\left(\chi^{2}(4)=\right.$ $18.06, p<.001)$. Related to Model 3, adding a random slope for the effect of time across students

Table 1 Means, standard deviations and one-way analyses of variance in positive and negative achievement emotions

\begin{tabular}{|c|c|c|c|c|c|c|c|c|}
\hline \multirow[t]{2}{*}{ Measure } & \multicolumn{2}{|l|}{$\mathrm{t} 1$} & \multicolumn{2}{|l|}{$\mathrm{t} 2$} & \multicolumn{2}{|l|}{ t3 } & \multirow[t]{2}{*}{$F$} & \multirow[t]{2}{*}{ Effect size $\eta$} \\
\hline & $M$ & $S D$ & $M$ & $S D$ & $M$ & $S D$ & & \\
\hline Enjoyment & 3.02 & 0.65 & 2.81 & 0.65 & 2.64 & 0.66 & $87.11^{*}$ & 0.054 \\
\hline Pride & 3.13 & 0.85 & 3.08 & 0.88 & 3.00 & 0.89 & $7.53 *$ & 0.004 \\
\hline Anxiety & 1.70 & 0.75 & 1.77 & 0.81 & 1.91 & 0.82 & $24.91^{*}$ & 0.013 \\
\hline Hopelessness & 1.43 & 0.69 & 1.55 & 0.84 & 1.71 & 0.87 & $34.80 *$ & 0.020 \\
\hline Boredom & 1.50 & 0.74 & 1.63 & 0.86 & 1.86 & 0.94 & $46.55^{*}$ & 0.030 \\
\hline
\end{tabular}

$t 1$, time point $1 ; t 2$, time point $2 ; t 3$, time point 3

$* p<.001$ 
Table 2 Multilevel growth curve model: Model parameters and goodness of fit for linear changes in the achievement emotion enjoyment

\begin{tabular}{|c|c|c|c|c|c|}
\hline \multirow[t]{2}{*}{ Effect } & \multicolumn{5}{|l|}{ Enjoyment } \\
\hline & Model 1 & Model 2 & Model 3 & Model 4 & Model 5 \\
\hline \multicolumn{6}{|l|}{ Fixed effects } \\
\hline Intercept & $3.26(0.01)^{* * *}$ & $3.26(0.02)^{* * *}$ & $3.64(0.03)^{* * * *}$ & $3.64(0.03)^{* * *}$ & $3.49(0.07)^{* * *}$ \\
\hline \multicolumn{6}{|c|}{ Linear rate of change } \\
\hline Time & & & $-0.19(0.03)^{* * *}$ & $-0.19(0.01)^{* * *}$ & $-0.19(0.01)^{* * *}$ \\
\hline Type of school & & & & & $0.11(0.04)^{* *}$ \\
\hline Gender & & & & & $-0.13(0.06)^{*}$ \\
\hline \multicolumn{6}{|l|}{ Random effects } \\
\hline Intercept & & 0.42 & 0.43 & 0.59 & 0.58 \\
\hline Time & & & & 0.18 & 0.18 \\
\hline Residual & & 0.45 & 0.41 & 0.37 & 0.37 \\
\hline ICC & & 0.46 & 0.52 & 0.71 & \\
\hline \multicolumn{6}{|l|}{ Goodness of fit } \\
\hline AIC & 3268.76 & 2933.35 & 2718.78 & 2700.85 & 2693.99 \\
\hline $\mathrm{BIC}$ & 3279.70 & 2949.75 & 2740.66 & 2733.66 & 2737.73 \\
\hline $\operatorname{logLik}$ & -1632.38 & -1463.67 & -1355.39 & -1344.43 & -1338.99 \\
\hline
\end{tabular}

Standard errors are in parentheses. Model 1, baseline model; Model 2, random intercept model without time; Model 3, random intercept model with time; Model 4, random intercept random slope model; Model 5, full model

Type of school was coded 0 for middle track schools and 1 for higher track schools

Gender was coded 0 for female and 1 for male

$* p<.05 ; * * p<.01 ; * * * p<.001$

(Model 4) significantly improved the model fit as well $\left(\chi^{2}(6)=18.62, p<.001\right)$. Additionally, Model 5 (including the type of school and gender as predictors) significantly improved the fit $\left(\chi^{2}(8)=7.35, p<.05\right)$. As can be seen in Table 3 , the effect of time $(\beta=-0.07(-0.10,-0.47)$, $t(1167)=-3.94, p<.001)$ is highly significant, revealing that pride changes significantly over the first year and the beginning of the second year of secondary school. Moreover, the standard deviation of intercepts is $0.74(0.64,0.85)$, and of slopes is $0.23(0.18,0.29)$. The type of school has a significant impact on the experience of pride as well $(\beta=0.14(0.02,0.25), t(581)=2.37, p$ $<.05)$, in favour of students at higher track schools. No significant gender effects were identified.

Moreover, the results of the multilevel growth curve model for the negative achievement emotion of anxiety reveal that the addition of a random intercept (Model 2) significantly improved the fit of the model $\left(\chi^{2}(3)=536.33, p<.001\right)$. Analogously, adding the fixed effect of time (Model 3) significantly improved the model fit $\left(\chi^{2}(4)=42.98, p<.001\right)$. Compared to Model 3, adding a random slope for the effect of time across students (Model 4) significantly improved the model fit as well $\left(\chi^{2}(6)=16.38, p<.001\right)$. Furthermore, the full model (including the type of school and gender as predictors) significantly improved the fit $\left(\chi^{2}(8)\right.$ $=10.44, p<.005)$. As Table 4 indicates, the effect of time $(\beta=0.09(0.07,0.13), t(1167)=$ $6.17, p<.001)$ is highly significant, which indicates that anxiety changes significantly during the first year and the beginning of the second year of secondary school. Furthermore, the standard deviation of intercepts is $0.64(0.56,0.74)$, and of slopes is $0.19(0.15,0.25)$. Moreover, a significant effect of the type of school is evident $(\beta=-0.17(-0.28,-0.07)$, $t(581)=-3.23, p<.001)$ : students entering a higher track school experience less anxiety 
Table 3 Multilevel growth curve model: Model parameters and goodness of fit for linear changes in the achievement emotion pride

\begin{tabular}{|c|c|c|c|c|c|}
\hline \multirow[t]{2}{*}{ Effect } & \multicolumn{5}{|l|}{ Pride } \\
\hline & Model 1 & Model 2 & Model 3 & Model 4 & Model 5 \\
\hline \multicolumn{6}{|l|}{ Fixed effects } \\
\hline Intercept & $3.46(0.02)^{* * *}$ & $3.46(0.03)^{* * *}$ & $3.60(0.04)^{* * *}$ & $3.60(0.04)^{* * *}$ & $3.39(0.09)^{* * *}$ \\
\hline \multicolumn{6}{|c|}{ Linear rate of change } \\
\hline Time & & & $-0.07(0.02)^{*}$ & $-0.07(0.02)^{*}$ & $-0.07(0.02)^{*}$ \\
\hline Type of school & & & & & $0.14(0.06)^{*}$ \\
\hline Gender & & & & & $0.08(0.08)$ \\
\hline \multicolumn{6}{|l|}{ Random effects } \\
\hline Intercept & & 0.61 & 0.61 & 0.74 & 0.74 \\
\hline Time & & & & 0.23 & 0.23 \\
\hline Residual & & 0.56 & 0.56 & 0.51 & 0.51 \\
\hline ICC & & 0.54 & 0.54 & 0.68 & \\
\hline \multicolumn{6}{|l|}{ Goodness of fit } \\
\hline $\mathrm{AIC}$ & 4327.70 & 3850.85 & 3834.79 & 3820.17 & 3816.82 \\
\hline BIC & 4338.64 & 3867.25 & 3856.66 & 3852.98 & 3860.57 \\
\hline $\operatorname{logLik}$ & -2161.85 & -1922.42 & -1913.39 & -1904.08 & -1900.41 \\
\hline
\end{tabular}

Standard errors are in parentheses. Model 1, baseline model; Model 2, random intercept model without time; Model 3, random intercept model with time; Model 4, random intercept random slope model; Model 5, full model Type of school was coded 0 for middle track schools and 1 for higher track schools

Gender was coded 0 for female and 1 for male

$* p<.05 ; * * p<.01 ; * * * p<.001$

Table 4 Multilevel growth curve model: Model parameters and goodness of fit for linear changes in the achievement emotion anxiety

\begin{tabular}{|c|c|c|c|c|c|}
\hline \multirow[t]{2}{*}{ Effect } & \multicolumn{5}{|l|}{ Anxiety } \\
\hline & Model 1 & Model 2 & Model 3 & Model 4 & Model 5 \\
\hline \multicolumn{6}{|l|}{ Fixed effects } \\
\hline Intercept & $2.23(0.02)^{* * *}$ & $2.23(0.03)^{* * *}$ & $2.03(0.04) * * *$ & $2.03(0.04) * * *$ & $2.28(0.09)^{* * *}$ \\
\hline \multicolumn{6}{|l|}{ Linear rate of change } \\
\hline Time & & & $0.10(0.01)^{* *}$ & $0.10(0.02)^{* *}$ & $0.10(0.02)^{* *}$ \\
\hline Type of school & & & & & $-0.17(0.05)^{* * *}$ \\
\hline Gender & & & & & $0.01(0.07)$ \\
\hline \multicolumn{6}{|l|}{ Random effects } \\
\hline Intercept & & 0.58 & 0.58 & 0.65 & 0.64 \\
\hline Time & & & & 0.19 & 0.19 \\
\hline Residual & & 0.51 & 0.50 & 0.46 & 0.46 \\
\hline ICC & & 0.57 & 0.58 & 0.67 & \\
\hline \multicolumn{6}{|l|}{ Goodness of fit } \\
\hline AIC & 4069.35 & 3535.02 & 3494.04 & 3481.66 & 3475.22 \\
\hline BIC & 4080.28 & 3551.42 & 3515.91 & 3514.47 & 3518.96 \\
\hline $\log$ Lik & -2032.67 & -1764.51 & -1743.02 & -1734.83 & -1729.61 \\
\hline
\end{tabular}

Standard errors are in parentheses. Model 1, baseline model; Model 2, random intercept model without time; Model 3, random intercept model with time; Model 4, random intercept random slope model; Model 5, full model Type of school was coded 0 for middle track schools and 1 for higher track schools Gender was coded 0 for female and 1 for male

$* p<.05 ; * * p<.01 ; * * * p<.001$ 
during the first year and the beginning of the second year of secondary school. No significant gender effects were detected.

With regard to the negative achievement emotion of hopelessness, the results of the multilevel growth curve model (see Table 5) reveal that adding a random intercept (Model 2 ) significantly improved the model fit $\left(\chi^{2}(3)=406.44, p<.001\right)$. Similarly, adding the fixed effect of time (Model 3) significantly improved the model fit $\left(\chi^{2}(4)=62.86, p<.001\right)$. Compared to Model 3, adding a random slope for the effect of time across students (Model 4) significantly improved the model fit as well $\left(\chi^{2}(6)=30.58, p<.001\right)$. Moreover, Model 5 (including the type of school and gender as predictors) significantly improved the fit $\left(\chi^{2}(8)=\right.$ $11.08, p<.005)$. The results of the analyses show a highly significant impact of time $(\beta=0.14$ $(0.10,0.17), t(1167)=7.68, p<.001)$, revealing that hopelessness changes significantly during the first year and the beginning of the second year of secondary school. Additionally, the standard deviation of intercepts is $0.49(0.43,0.56)$, and of slopes is $0.18(0.15,0.21)$. An effect of the type of school is evident $(\beta=-0.18(-0.29,-0.07), t(581)=-3.26, p<.001)$, while gender has no significant impact on the development of hopelessness.

The last examined negative achievement emotion was boredom. The results of the multilevel growth curve model (see Table 6) show that the addition of a random intercept (Model 2) significantly improved the fit of the model $\left(\chi^{2}(3)=297.15, p<.001\right)$. Analogously, adding the fixed effect of time (Model 3) significantly improved the model fit $\left(\chi^{2}(4)=90.05, p<.001\right)$. Compared to Model 3, adding a random slope for the effect of time across students (Model 4) significantly improved the model fit as well $\left(\chi^{2}(6)=48.26, p<.001\right)$. The full model

Table 5 Multilevel growth curve model: Model parameters and goodness of fit for linear changes in the achievement emotion hopelessness

\begin{tabular}{|c|c|c|c|c|c|}
\hline \multirow[t]{2}{*}{ Effect } & \multicolumn{5}{|l|}{ Hopelessness } \\
\hline & Model 1 & Model 2 & Model 3 & Model 4 & Model 5 \\
\hline \multicolumn{6}{|l|}{ Fixed effects } \\
\hline Intercept & $1.87(0.02)^{* * *}$ & $1.87(0.03)^{* * *}$ & $1.59(0.04)^{* * *}$ & $1.59(0.04)^{* * *}$ & $1.86(0.09)^{* * *}$ \\
\hline \multicolumn{6}{|c|}{ Linear rate of change } \\
\hline Time & & & $0.14(0.02)^{* * *}$ & $0.14(0.02)^{* * * *}$ & $0.14(0.02)^{* * *}$ \\
\hline Type of school & & & & & $-0.18(0.06)^{* * *}$ \\
\hline Gender & & & & & $-0.02(0.08)$ \\
\hline \multicolumn{6}{|l|}{ Random effects } \\
\hline Intercept & & 0.60 & 0.60 & 0.50 & 0.49 \\
\hline Time & & & & 0.18 & 0.18 \\
\hline Residual & & 0.60 & 0.58 & 0.55 & 0.55 \\
\hline ICC & & 0.50 & 0.52 & 0.45 & \\
\hline \multicolumn{6}{|l|}{ Goodness of fit } \\
\hline $\mathrm{AIC}$ & 4384.11 & 3979.67 & 3918.81 & 3892.23 & 3885.15 \\
\hline $\mathrm{BIC}$ & 4395.05 & 3996.08 & 3940.69 & 3925.04 & 3928.90 \\
\hline logLik & -2190.06 & -1986.84 & -1955.41 & -1940.12 & -1934.57 \\
\hline
\end{tabular}

Standard errors are in parentheses. Model 1, baseline model; Model 2, random intercept model without time; Model 3, random intercept model with time; Model 4, random intercept random slope model; Model 5, full model

Type of school was coded 0 for middle track schools and 1 for higher track schools

Gender was coded 0 for female and 1 for male

$* p<.05 ; * * p<.01 ; * * * p<.001$ 
Table 6 Model parameters and goodness of fit for linear changes in the achievement emotion boredom

\begin{tabular}{|c|c|c|c|c|c|}
\hline \multirow{2}{*}{ Effect } & \multicolumn{5}{|l|}{ Boredom } \\
\hline & Model 1 & Model 2 & Model 3 & Model 4 & Model 5 \\
\hline \multicolumn{6}{|l|}{ Fixed effects } \\
\hline Intercept & $1.97(0.02)^{* * *}$ & $1.97(0.03)^{* * *}$ & $1.61(0.05)^{* * *}$ & $1.61(0.04)^{* * *}$ & $1.73(0.09)^{* * *}$ \\
\hline \multicolumn{6}{|c|}{ Linear rate of change } \\
\hline Time & & & $0.18(0.02)^{* * *}$ & $0.18(0.02)^{* * *}$ & $0.18(0.02) * * *$ \\
\hline Type of school & & & & & $-0.11(0.06)^{*}$ \\
\hline Gender & & & & & $0.25(0.08)^{* *}$ \\
\hline \multicolumn{6}{|l|}{ Random effects } \\
\hline Intercept & & 0.58 & 0.59 & 0.62 & 0.61 \\
\hline Time & & & & 0.28 & 0.28 \\
\hline Residual & & 0.66 & 0.64 & 0.57 & 0.57 \\
\hline ICC & & 0.43 & 0.46 & 0.54 & \\
\hline \multicolumn{6}{|l|}{ Goodness of fit } \\
\hline AIC & 4517.65 & 4222.49 & 4134.44 & 4090.18 & 4081.93 \\
\hline $\mathrm{BIC}$ & 4528.58 & 4238.90 & 4156.32 & 4122.99 & 4125.67 \\
\hline $\operatorname{logLik}$ & -2256.82 & -2108.25 & -2063.22 & -2039.09 & -2032.96 \\
\hline
\end{tabular}

Standard errors are in parentheses. Model 1, baseline model; Model 2, random intercept model without time; Model 3, random intercept model with time; Model 4, random intercept random slope model; Model 5, full model

Type of school was coded 0 for middle track schools and 1 for higher track schools

Gender was coded 0 for female and 1 for male

$* p<.05 ; * * p<.01 ; * * * p<.001$

(including the type of school and gender as predictors) also significantly improved the fit $\left(\chi^{2}(8)=12.26, p<.005\right)$. The model shows that time $(\beta=0.18(0.14,0.22), t(1167)=8.87, p$ $<.001)$ is highly significant, which indicates that the negative achievement emotion of boredom significantly increases during the first year and the beginning of the second year of secondary school. Moreover, the standard deviation of intercepts is $0.61(0.49,0.75)$, and of slopes is $0.28(0.22,0.34)$. Furthermore, the type of school has a small but significant effect on the development of boredom $(\beta=-0.11(-0.22,0.01), t(581)=-1.93, p<.05)$ : students from higher track schools experience less boredom than students from middle track schools do. With regard to gender, an effect is also evident: boys experience significantly more boredom than girls do in the course of the first year and the beginning of the second year of secondary school $(\beta=0.25(0.09,0.40), t(581)=3.18, p<.005)$.

\section{Discussion}

\section{Theoretical significance}

This long-term study has revealed the extent to which achievement emotions develop after the transition from primary to secondary school in selected secondary schools in Germany. Thus, it offers a noteworthy contribution to existing research on achievement emotions - both positive and negative - in this context.

Previous studies have pointed to empirical findings on the development of achievement emotions in students (e.g. Pekrun et al. 2007; Vierhaus et al. 2016). However, the design of 
those studies is mostly cross-sectional (e.g. Goetz et al. 2012; Raccanello et al. 2013). Furthermore, there is little evidence of the development of negative achievement emotions such as hopelessness and boredom (Pekrun et al. 2018). Using multilevel growth curve models, the current study was designed to examine systematic changes in the development of the positive and negative achievement emotions of enjoyment, pride, anxiety, hopelessness and boredom between the fifth and sixth grades in the context of the transition from primary to secondary school. This transition understandably involves many changes and challenges for the students involved (Dias and Sá 2014).

The results of the study confirm Hypothesis 1 and show that the level of the positive achievement emotions of enjoyment and pride is quite high at the beginning of the fifth grade, but decreases steadily during the first year of secondary school - a finding which is consistent with the results of other studies (e.g. Bieg et al. 2019; Pekrun et al. 2007; Vierhaus et al. 2016). The most significant changes were recorded from $t 2$ to $t 3$, which can be explained by the fact that confirmed positive expectations on the part of the students after the transition (e.g. van Ophuysen 2009) cushion the decrease in positive achievement emotions between $\mathrm{t} 1$ and $\mathrm{t} 2$. In addition, steadily increasing achievement pressure and rising expectations during the first year of secondary school could lead to a stronger decline of positive achievement emotions in the second half of the school year.

In accordance with Hypothesis 2 and previous studies (e.g. Bieg et al. 2019; Pekrun et al. 2007), our results show that the negative achievement emotions of anxiety, hopelessness and boredom start at a relatively low level in the fifth grade and show a constant increase thereafter. Similar to the positive achievement emotions, the negative achievement emotions show their downward trend especially from $t 2$ to $t 3$. Thus, the courses of the positive achievement emotions of enjoyment and pride and the negative achievement emotions of anxiety, hopelessness and boredom are almost reversed, which is consistent with previous studies (e.g. Pekrun et al. 2007).

Regarding Hypothesis 3, our results show that students in higher track schools start with higher levels of positive achievement emotions (in line with Harazd and Schürer 2006; van Ophuysen 2008), but that the decline in these achievement emotions is comparatively worse than for students in middle track schools. Concerning the development of negative achievement emotions during the first year of secondary school, the situation is reversed. Students entering middle track schools start with higher levels of boredom, hopelessness and anxiety, but the increase in these achievement emotions is comparatively lower than for students in higher track schools (for anxiety see Eder 2007; Goetz et al. 2004; Valtin and Wagner 2004). With regard to the tripartite school system in Germany, the results of the study show the discrepancies in the development of positive and negative achievement emotions in the first years of secondary school between the different types of school. Especially in higher track schools the high level of motivation, pride and enjoyment (e.g. van Ophuysen 2008) after the transition from primary to secondary school seems to decline rather quickly and the further development of positive and negative achievement emotions in higher track schools is rather unfavourable. These differences in the development may result from the varying academic requirements and different educational tasks that students of different types of schools within the tripartite school system are confronted with (ISB 2019). The more significant decline in positive achievement emotions and increase in negative achievement emotions in higher track schools could also be attributed to frame of reference effects (Marsh and Hau 2003): students entering a higher track school have a lower achievement status in their new class, which - in conjunction with achievement pressure - can lead to the development of unfavourable 
achievement emotions in the first year of secondary school. Moreover, the development of negative achievement emotions, especially in higher track schools, could be explained by decreasing self-efficacy expectations (cf. big-fish-little-pond effect-see Marsh and Parker 1984), which in turn, may be associated with an increase in anxiety and a decrease in enjoyment and pride (e.g. Eder 2007).

The results of this study confirm Hypothesis 4, showing that boys feel less enjoyment than girls do, which is in line with the findings of Gentry et al. (2002). With regard to negative achievement emotions, the gender differences in boredom were confirmed (e.g. Daniels et al. 2009). With respect to pride, anxiety and hopelessness, no gender-specific effects were revealed.

Possible reasons for the rather unfavourable changes in the development of positive and negative achievement emotions during the first year and the beginning of the second year of secondary school may be the new social environment, an increase in teacher-centred instruction, a decline in the cognitive activation perceived by students, and a lack of perceived support from teachers (Dias and Sá 2014; Lazarides and Buchholz 2019; van Ophuysen 2009). In this context, Lazarides and Buchholz (2019) point out that weaknesses in classroom management are particularly related to the development of boredom, while perceived support for students is relevant to the achievement emotions of enjoyment and anxiety.

\section{Limitations}

This study has some limitations that should be identified and discussed when interpreting the results. Firstly, the study focused on students' achievement emotions in class in general; domain-specific differences between subjects (e.g. Goetz et al. 2006) were not examined. In further research, the development of achievement emotions should also be analysed while taking different school subjects into account (e.g. Pekrun et al. 2007), in order to examine the correlations and interactions between domain-specific learning conditions and specific emotional experiences. Furthermore, in the present study, a global scale was generated for each achievement emotion. In further research, it would be interesting to examine the development of different achievement emotions while taking different aspects as the setting (emotions in class, during a test and during homework), or social interactions into account (Pekrun et al. 2005; Schlesier 2020).

Secondly, when interpreting the data, it should be noted that this is a regional and possibly non-representative sample, which limits the possibility of drawing universal conclusions. In particular, the differences in the type of school could be attributed to the specificity of the individual profile of private schools in Germany under ecclesiastical sponsorship (Nothaft 2012). Nevertheless, similar effects may be found in other studies of state schools (e.g. Pekrun et al. 2007).

Another limitation that needs to be addressed is the question of whether the students can make meaningful and - in terms of their emotional experience - significant assessments of the classes they have attended for only a few weeks after entering secondary school.

Finally, another limitation of this study is the rather unequal gender ratio, due to many mono-educational schools for girls being included in the sample. Possible gender effects (or lack thereof) on the development of positive and negative achievement emotions should therefore be carefully interpreted and investigated in subsequent follow-up studies. 


\section{Implications and future directions}

With regard to the impact of research on the development of achievement emotions in the first year and the beginning of the second year of secondary school, an important aspect is that teachers need to be aware of their potential to influence students' achievement emotions - in particular, they need to try to support positive achievement emotions while reducing negative achievement emotions (Goetz and Hall 2013). The promotion of students' emotional regulation skills is relevant in this context (Schlesier et al. 2019; Brackett and Rivers 2014; Zeidner 2007). Training programmes for the promotion of emotional competencies (e.g. Petermann et al. 2016) are necessary in order to expand students' repertoire of emotional regulation strategies. Social-emotional learning (SEL) programmes may help students to practise emotional intelligence skills, such as the ability to identify positive and negative emotions (Brackett and Rivers 2014). It is also important for teachers to exemplify positive achievement emotions in the classroom (Frenzel et al. 2015), since they function as role models. In addition, teachers should try to improve students' academic self-concept and self-confidence, both of which are related to the experience of positive achievement emotions (Goetz et al. 2008).

The control-value approach (Pekrun 2006) confirms the influence of individual and contextual determinants (e.g. Lazarides and Buchholz 2019). In order to counteract the development of negative achievement emotions during the course of secondary school, teachers should do the following: provide students with autonomy to self-regulate their learning in the classroom, consider aspects of classroom management and encourage a positive relationship between teachers and students (Gläser-Zikuda and Fuß 2008; Lazarides and Buchholz 2019). Adaptive instruction, different forms of feedback (Hattie and Timperley 2007) and formative assessment (portfolios, learning diaries, rubrics etc.) are important for students' motivation and thus for their emotional experience (e.g. Gläser-Zikuda and Hascher 2007).

\section{Conclusion}

Despite the limitations described, this study contributes to research on achievement emotions, specifically since we examined the development of the previously neglected achievement emotions of boredom and hopelessness. The study reveals that the first year and the beginning of the second year of secondary school is associated with a rather adverse development of both positive and negative achievement emotions. In order to cushion this adverse development, the study suggests techniques for teachers and students, such as emotional regulation and aspects of classroom management. The study provides a basis for subsequent research in which further reasons for this rather unfavourable development of achievement emotions during secondary school could be examined. In this context, followup studies should also examine the development of positive and negative achievement emotions with a focus on teacher-student interaction as well as domain-specific differences between subjects.

Funding Open Access funding enabled and organized by Projekt DEAL. This research was supported by a research grant to Michaela Gläser-Zikuda (University of Erlangen-Nuremberg, School Education and 
Instructional Research, Germany) from the Catholic School Foundation of Bavaria (Katholisches Schulwerk Bayern). We greatly appreciate the funding, the cooperation, and the supervision of the paper.

\section{Declarations}

Conflict of interest The authors declare no competing interests.

Open Access This article is licensed under a Creative Commons Attribution 4.0 International License, which permits use, sharing, adaptation, distribution and reproduction in any medium or format, as long as you give appropriate credit to the original author(s) and the source, provide a link to the Creative Commons licence, and indicate if changes were made. The images or other third party material in this article are included in the article's Creative Commons licence, unless indicated otherwise in a credit line to the material. If material is not included in the article's Creative Commons licence and your intended use is not permitted by statutory regulation or exceeds the permitted use, you will need to obtain permission directly from the copyright holder. To view a copy of this licence, visit http://creativecommons.org/licenses/by/4.0/.

\section{References}

Ahmed, W., van der Werf, G., Kuyper, H., \& Minnaert, A. (2013). Emotions, self-regulated learning, and achievement in mathematics: a growth curve analysis. Journal of Educational Psychology, 105(1), 150-161. https://doi.org/10.1037/a0030160.

Becker, M., Neumann, M., Tetzner, J., Böse, S., Knoppick, H., Maaz, K., Baumert, J., \& Lehmann, R. (2014). Is early ability grouping good for high-achieving students' psychosocial development? Effects of the transition into academically selective schools. Journal of Educational Psychology, 106(2), 555-568. https://doi.org/10. 1037/a0035425.

Bieg, S., Grassinger, R., \& Dresel, M. (2019). Teacher humor: longitudinal effects on students' emotions. European Journal of Psychology of Education, 34(3), 517-534. https://doi.org/10.1007/s10212-0180402-0.

Brackett, M. A., \& Rivers, S. E. (2014). Transforming students' lives with social and emotional learning. In R. Pekrun \& L. Linnenbrink-Garcia (Eds.), International handbook of emotions in education (pp. 368-388). New York: Routledge/Taylor \& Francis.

Buff, A. (2014). Enjoyment of learning and its personal antecedents: testing the change-change assumption of the control-value theory of achievement emotions. Learning and Individual Differences, 2014, 21-29. https://doi.org/10.1016/j.lindif.2013.12.007.

Daniels, L. M., Stupnisky, R. H., Pekrun, R., Haynes, T. L., Perry, R. P., \& Newall, N. E. (2009). A longitudinal analysis of achievement goals: from affective antecedents to emotional effects and achievement outcomes. Journal of Educational Psychology, 101(4), 948-963. https://doi.org/10.1037/a0016096.

Deci, E. L., \& Ryan, R. M. (Eds.). (2002). Handbook of self-determination research. Rochester, NY: University of Rochester Press.

Dias, D., \& Sá, M. J. (2014). The impact of the transition to HE: emotions, feelings and sensations. European Journal of Education, 49(2), 291-303. https://doi.org/10.1111/ejed.12058.

Eccles, J. S., \& Midgley, C. (1989). Stage-environment fit: developmentally appropriate classrooms for young adolescents. Research on Motivation in Education, 3(2), 139-186. https://doi.org/10.1037/0003-066X.48.2. 90.

Eder, F. (2007). Das Befinden von Kindern und Jugendlichen in der österreichischen Schule. Befragung 2005 [The well-being of children and young people in Austrian schools. Survey 2005] (Bildungsforschung des Bundesministeriums für Bildung, Wissenschaft und Kultur). Innsbruck: Studienverlag.

Field, A., Miles, J., \& Field, Z. (2012). Discovering statistics using R. LA, London, New Delhi, Singapore, Washington DC: Sage.

Filipp, S.-H. (2001). Adulthood: developmental tasks and critical life events. In N. J. Smelser \& P. B. Baltes (Eds.), International encyclopedia of the social and behavioral sciences (pp. 153-156). Oxford: Elsevier Science.

Frenzel, A. C., Goetz, T., \& Pekrun, R. (2015). Emotionen [Emotions]. In E. Wild \& J. Möller (Eds.), Pädagogische Psychologie (pp. 201-224). Berlin, Heidelberg: Springer. 
Frenzel, A. C., Thrash, T. M., Pekrun, R., \& Goetz, T. (2007). Achievement emotions in Germany and China: a cross-cultural validation of the Academic Emotions Questionnaire-Mathematics. Journal of CrossCultural Psychology, 38(3), 302-309. https://doi.org/10.1177/0022022107300276.

Gentry, M., Gable, R. K., \& Rizza, M. G. (2002). Students' perceptions of classroom activities: are there gradelevel and gender differences? Journal of Educational Psychology, 94(3), 539-544. https://doi.org/10.1037/ 0022-0663.94.3.539.

Gläser-Zikuda, M., Fuß, S., Laukenmann, M., Metz, K., \& Randler, C. (2005). Promoting students' emotions and achievement - instructional design and evaluation of the ECOLE approach. Learning and Instruction, 15(5), 481-495. https://doi.org/10.1016/j.learninstruc.2005.07.013.

Gläser-Zikuda, M., \& Fuß, S. (2008). Impact of teacher competencies on student emotions. A multi-method approach. International Journal of Educational Research, 47(2), 136-147. https://doi.org/10.1016/j.ijer. 2007.11.013.

Gläser-Zikuda, M., \& Hascher, T. (2007). Zum Potenzial von Lerntagebuch und Portfolio [The potential of learning diaries and portfolios]. In M. Gläser-Zikuda \& T. Hascher (Eds.), Lernprozesse dokumentieren, reflektieren und beurteilen. Lerntagebuch, \& Portfolio in Bildungsforschung und Bildungspraxis (pp. 9-21). Klinkhardt: Bad Heilbrunn.

Goetz, T., Bieg, M., Lüdtke, O., Pekrun, R., \& Hall, N. C. (2013). Do girls really experience more anxiety in mathematics? Psychological Science, 24(10), 2079-2087. https://doi.org/10.1177/ 0956797613486989.

Goetz, T., Frenzel, A. C., Hall, N. C., \& Pekrun, R. (2008). Antecedents of academic emotions: testing the internal/external frame of reference model for academic enjoyment. Contemporary Educational Psychology, 33(1), 9-33. https://doi.org/10.1016/j.cedpsych.2006.12.002.

Goetz, T., Frenzel, A. C., Pekrun, R., \& Hall, N. C. (2006). The domain specificity of academic emotional experiences. The Journal of Experimental Education, 75(1), 5-29. https://doi.org/10.3200/JEXE.75.1.5-29.

Goetz, T., \& Hall, N. C. (2013). Emotion and achievement in the classroom. In J. Hattie \& E. M. Anderman (Eds.), International guide to student achievement (pp. 192-195). New York: Routledge.

Goetz, T., Nett, U. E., Martiny, S. E., Hall, N. C., Pekrun, R., Dettmers, S., \& Trautwein, U. (2012). Students' emotions during homework: structures, self-concept antecedents, and achievement outcomes. Learning and Individual Differences, 22(2), 225-234. https://doi.org/10.1016/j.lindif.2011.04.006.

Goetz, T., Pekrun, R., Zirngibl, A., Jullien, S., Kleine, M., Vom Hofe, R., \& Blum, W. (2004). Leistung und emotionales Erleben im Fach Mathematik. Längsschnittliche Mehrebenenanalysen [Academic achievement and emotions in mathematics: a longitudinal multilevel analysis perspective]. Zeitschrift für Pädagogische Psychologie, 18(3/4), 201-212. https://doi.org/10.1024/1010-0652.18.34.201.

Hagenauer, G., \& Hascher, T. (2010). Learning enjoyment in early adolescence. Educational Research and Evaluation, 16(6), 495-516. https://doi.org/10.1080/13803611.2010.550499.

Harazd, B., \& Schürer, S. (2006). Veränderung der Schulfreude von der Grundschule zur weiterführenden Schule [Change in the liking of school from primary to secondary school]. In A. Schründer-Lenzen (Ed.), Risikofaktoren kindlicher Entwicklung [Risk factors of child development] (pp. 208-222). Wiesbaden: VS. https://doi.org/10.1007/978-3-531-90075-9 11.

Hascher, T. (2007). Exploring students' well-being by taking a variety of looks into the classroom. Hellenic Journal of Psychology, 4(1), 331-349. https://doi.org/10.2304/eerj.2010.9.1.13.

Hattie, J., \& Timperley, H. (2007). The power of feedback. Review of Educational Research, 77(1), 81-112. https://doi.org/10.3102/003465430298487.

Helmke, A. (1993). Die Entwicklung der Lernfreude vom Kindergarten bis zur 5. Klasse [The development of enjoyment of learning from kindergarten to grade 5]. Zeitschrift für Pädagogische Psychologie, 7, $77-86$.

Hosoya, G., Koch, T., \& Eid, M. (2014). Längsschnittdaten und Mehrebenenanalysen [Longitudinal data and multilevel analysis]. Kölner Zeitschrift für Soziologie und Sozialpsychologie, 66(S1), 189-218. https://doi. org/10.1007/s1 1577-014-0262-9.

ISB (Staatsinstitut für Schulqualität und Bildungsforschung) (2019). LehrplanPLUS. Munich. Retrieved from: https://www.lehrplanplus.bayern.de/ [22.09.2020].

Lazarides, R., \& Buchholz, J. (2019). Student-perceived teaching quality: how is it related to different achievement emotions in mathematics classrooms? Learning and Instruction, 61, 45-59. https://doi.org/10.1016/j. learninstruc.2019.01.001.

Lichtenfeld, S., Pekrun, R., Stupnisky, R. H., Reiss, K., \& Murayama, K. (2012). Measuring students' emotions in the early years: the Achievement Emotions Questionnaire-Elementary School (AEQ-ES). Learning and Individual Differences, 22(2), 190-201. https://doi.org/10.1016/j.lindif.2011.04.009.

Linnenbrink, E. A. (2007). The role of affect in student learning: a multi-dimensional approach to considering the interaction of affect, motivation and engagement. In P. A. Schutz \& R. Pekrun (Eds.), Emotion in education (pp. 107-124). Amsterdam: Elsevier. https://doi.org/10.1016/B978-012372545-5/50008-3. 
Marsh, H. W., \& Parker, J. W. (1984). Determinants of student self-concept: is it better to be a relatively large fish in a small pond even if you don't learn to swim as well? Journal of Personality and Social Psychology, 47(1), 213-231. https://doi.org/10.1037/0022-3514.47.1.213.

Marsh, H. W., \& Hau, K.-T. (2003). Big-fish-little-pond effect on academic self-concept: a cross-cultural (26-country) test of the negative effects of academically selective schools. American Psychologist, 58(5), 364-376. https://doi.org/10.1037/0003-066X.58.5.364.

Marsh, H. W., Trautwein, U., Lüdtke, O., Baumert, J., \& Köller, O. (2007). The big-fish-little-pond effect. Persistent negative effects of selective high schools on self-concept after graduation. American Educational Research Journal, 44(3), 631-669. https://doi.org/10.3102/0002831207306728.

Mega, C., Ronconi, L., \& De Beni, R. (2014). What makes a good student? How emotions, self-regulated learning, and motivation contribute to academic achievement. Journal of Educational Psychology, 106(1), 121-131. https://doi.org/10.1037/a0033546.

Meyer, S., \& Gläser-Zikuda, M. (2020). Zur Bedeutung individueller und kontextueller Einflussfaktoren auf Lern- und Leistungsemotionen zu Beginn der Sekundarstufe - eine mehrebenenanalytische Betrachtung [Individual and contextual determinants of achievement emotions at the beginning of secondary school - a multilevel analysis]. Zeitschrift für Bildungsforschung, 10, 81-102. https://doi.org/10.1007/s35834-01900258-y.

Nothaft, P. (2012). Ermöglichung als Schlüsselbegriff für die Entwicklung Katholischer Schulen [Enabling as a key concept for the development of Catholic schools]. Muenster: LIT.

Peixoto, F., Mata, L., Monteiro, V., Sanches, C., \& Pekrun, R. (2015). The Achievement Emotions Questionnaire: validation for pre-adolescent students. European Journal of Developmental Psychology, 12(4), 472-481. https://doi.org/10.1080/17405629.2015.1040757.

Pekrun, R. (2006). The control-value theory of achievement emotions: assumptions, corollaries, and implications for educational research and practice. Educational Psychology Review, 18(4), 315-341. https://doi.org/10. 1007/s10648-006-9029-9.

Pekrun, R. (2016). Academic emotions. In K. R. Wentzel \& D. B. Miele (Eds.), Handbook of motivation at school (pp. 120-144). New York: Taylor \& Francis.

Pekrun, R. (2017). Emotion and achievement during adolescence. Child Development Perspectives, 11(3), 215221. https://doi.org/10.1111/cdep.12237.

Pekrun, R., Goetz, T., Daniels, L. M., Stupnisky, R. H., \& Perry, R. P. (2010). Boredom in achievement settings: exploring control-value antecedents and performance outcomes of a neglected emotion. Journal of Educational Psychology, 102(3), 531-549. https://doi.org/10.1037/a0019243.

Pekrun, R., Goetz, T., \& Frenzel, A. C. (2005). Academic Emotions Questionnaire-Mathematics (AEQ-M): user's manual. Munich: University of Munich, Department of Psychology.

Pekrun, R., Goetz, T., Frenzel, A. C., Barchfeld, P., \& Perry, R. P. (2011). Measuring emotions in students' learning and performance: the Achievement Emotions Questionnaire (AEQ). Contemporary Educational Psychology, 36(1), 36-48. https://doi.org/10.1016/j.cedpsych.2010.10.002.

Pekrun, R., Lichtenfeld, S., Marsh, H. W., Murayama, K., \& Goetz, T. (2017). Achievement emotions and academic performance. Longitudinal models of reciprocal effects. Child Development, 88(5), 1653-1670. https://doi.org/10.1111/cdev.12704.

Pekrun, R., \& Linnenbrink-Garcia, L. (Eds.). (2014). International handbook of emotions in education. New York: Taylor \& Francis.

Pekrun, R., Muis, K. R., Frenzel, A. C., \& Goetz, T. (2018). Emotions at school. New York: Routledge.

Pekrun, R., \& Perry, R. P. (2014). Control-value theory of achievement emotions. In R. Pekrun \& L. Linnenbrink-Garcia (Eds.), International handbook of emotions in education (pp. 120-141). New York: Taylor \& Francis.

Pekrun, R., vom Hofe, R., Blum, W., Frenzel, A. C., Goetz, T., \& Wartha, S. (2007). Development of mathematical competencies in adolescence: the PALMA longitudinal study. In M. Prenzel (Ed.), Studies on the educational quality of schools: the final report on the DFG priority programme (pp. 17-37). Muenster: Waxmann.

Petermann, F., Petermann, U., \& Nitkowski, D. (2016). Emotionstraining in der Schule. Ein Programm zur Förderung der emotionalen Kompetenz. [Emotional training in school. A programme to promote emotional competence]. Göttingen: Hogrefe.

Raccanello, D., Brondino, M., \& De Bernardi, B. (2013). Achievement emotions in elementary, middle, and high school: how do students feel about specific contexts in terms of settings and subject domains? Scandinavian Journal of Psychology, 54(6), 477-484. https://doi.org/10.1111/sjop.12079.

Scherer, K. R. (2009). The dynamic architecture of emotions: evidence for the component process model. Cognition and Emotion, 23(7), 1307-1351. https://doi.org/10.1080/02699930902928969. 
Schlesier, J. (2020). Lern- und Leistungsemotionen, Emotionsregulation und Lehrkraft-Schulkind-Interaktion: Ein integratives Modell [Learning and performance emotions, emotion regulation and teacher-studentinteraction: an integrated model]. 1st ed., Klinkhardt.

Schlesier, J., Roden, I., \& Moschner, B. (2019). Emotion regulation in primary school children: A systematic review. Children and Youth Services Review, 100, 239-257. https://doi.org/10.1016/j.childyouth.2019.02. 044.

Symonds, J., \& Hargreaves, L. (2016). Emotional and motivational engagement at school transition: a qualitative stage-environment fit study. The Journal of Early Adolescence, 36(1), 54-85. https://doi.org/10.1177/ 0272431614556348 .

Valtin, R., \& Wagner, C. (2004). Der Übergang in die Sekundarstufe I: Psychische Kosten der externen Leistungsdifferenzierung [Transition to secondary school. Psychological side-effects of external differentiation in school tracks]. Psychologie in Erziehung und Unterricht, 51, 52-68.

van Ophuysen, S. (2008). Zur Veränderung der Schulfreude von Klasse 4 bis 7 [How the liking of school changes from grade 4 to 7 . A longitudinal study on school-type specific effects of holidays and primary school transition]. Zeitschrift für Pädagogische Psychologie, 22(3/4), 293-306. https://doi.org/10.1024/ 1010-0652.22.34.293.

van Ophuysen, S. (2009). Moving to secondary school: on the role of affective expectations in a tracking school system. European Educational Research Journal, 8(3), 434-446. https://doi.org/10.2304/eerj. 2009.8.3.434

Vierhaus, M., Lohaus, A., \& Wild, E. (2016). The development of achievement emotions and coping/emotion regulation from primary to secondary school. Learning and Instruction, 42, 12-21. https://doi.org/10.1016/j. learninstruc.2015.11.002.

Zeidner, M. (2007). Test anxiety: conceptions, findings, conclusions. In P. A. Schutz \& R. Pekrun (Eds.), Emotion in education (pp. 165-184). San Diego, CA: Academic Press.

Zeidner, M. (2014). Anxiety in education. In R. Pekrun \& L. Linnenbrink-Garcia (Eds.), International handbook of emotions in education (pp. 265-288). New York: Taylor \& Francis.

Zeidner, M., \& Schleyer, E. J. (1999). The big-fish-little-pond effect for academic self-concept, test anxiety, and school grades in gifted children. Contemporary Educational Psychology, 24(4), 305-329. https://doi.org/10. 1006/ceps.1998.0985.?

Publisher's Note Springer Nature remains neutral with regard to jurisdictional claims in published maps and institutional affiliations.

Current themes of research inclusion and mind literacy:

Simon Meyer: Learning and performance emotions (achievement emotions). Motivation. Transition to secondary school. Diversity.

Juiane Schlesier: Learning and performance emotions (achievement emotions). Emotion regulation. Teacherstudent-interaction. Teacher education/primary education. Research methods (empirical research on learning and instruction).

\section{Most relevant publications}

\section{Simon Meyer:}

\section{Peer-reviewed journals}

Meyer, S., \& Gläser-Zikuda, M. (2020). Zur Bedeutung individueller und kontextueller Einflussfaktoren auf Lern- und Leistungsemotionen zu Beginn der Sekundarstufe - eine mehrebenenanalytische Betrachtung [Individual and contextual determinants of achievement emotions at the beginning of secondary school - a multilevel analysis]. Zeitschrift für Bildungsforschung, 10, 81-102. https://doi.org/10.1007/s35834-01900258-y.

\section{Book contributions}

Meyer, S., Obermeier, R., \& Gläser-Zikuda, M. (2021). Lern- und Leistungsemotionen im Kontext schulischer Transition [Achievement emotions in the context of school transition]. Kohlhammer. 


\section{Conference contributions}

Meyer, S., Obermeier, R., \& Gläser-Zikuda, M. (2019). Individual and contextual determinants of achievement emotions at the beginning of secondary school - a multilevel analysis. European Association for Research on Learning and Instruction (EARLI Conference), 12.08.-16.08.2019, RWTH Aachen (Single Paper).

Meyer, S., \& Gläser-Zikuda, M. (2018). Individuelle und kontextuelle Einflussfaktoren auf Lern- und Leistungsemotionen zu Beginn der Sekundarstufe - eine mehrebenenanalytische Betrachtung. Conference of the "Arbeitsgruppe für Empirische Pädagogische Forschung (AEPF)", 24.09.-26.09.2018, Leuphana University Lüneburg (Single Paper).

Meyer, S. \& Gläser-Zikuda, M. (2018). Prüfungsangst von Schüler/innen zu Beginn der Sekundarstufe I Individuelle und kontextuelle Prädiktoren. Conference of the "Deutsche Gesellschaft für Psychologie (DGPs)", 15.09.-20.09.2018, Goethe-University Frankfurt (Single Paper).

\section{Juliane Schlesier:}

\section{Peer-reviewed journals}

Schlesier, J. (2020). Lern- und Leistungsemotionen, Emotionsregulation und Lehrkraft-Schulkind-Interaktion: Ein integratives Modell [Learning and performance emotions, emotion regulation and teacher-student-interaction: an integrated model]. 1st ed., Klinkhardt.

Wagener, U., Reimer, M., Lüschen, I., Schlesier, J., \& Moschner, B. (2019). "Krass auf das Lehramt bezogen” Lehramtsstudierende wünschen sich mehr Kohärenz in ihrem Lehramtsstudium [Teacher students ask for more coherence in their educational programs]. Herausforderung Lehrer_innenbildung, 2(1), 216-226, doi: https://doi.org/10.4119/UNIBI/hlz-215.

Schlesier, J., Roden, I., \& Moschner, B. (2019). Emotion regulation in primary school children: A systematic review. Children and Youth Services Review, 100, 239-257. https://doi.org/10.1016/j.childyouth.2019.02. 044.

Book contributions

Schlesier, J., Wagener, U., \& Moschner, B. (2019). Beobachtung als Methode zur Erforschung des selbstregulierten Lernens bei Grundschulkindern [Observation as a research method to explore selfregulated learning in primary school children]. In Hartnack, F. (Hrsg.), Qualitative Forschung mit Kindern (279-310). Wiesbaden: Springer VS. doi: https://doi.org/10.1007/978-3-658-24564-1_9.

Lohbeck, A., Schlesier, J., Wagener, U., \& Moschner, B. (2018). Emotionsregulationsstrategien, Emotionen und kognitive Lernstrategien von Studierenden [Students' emotion regulation strategies, emotions and cognitive learning strategies]. In Hagenauer, G., \& Hascher, T. (Hrsg.), Emotionen und Emotionsregulation in Schule und Hochschule (52-72). Münster, New York: Waxmann.

Schlesier, J. (2017). Lehrervorstellungen zur Entwicklung der Emotionsregulation im schulischen Kontext der Primarstufe [Primary school teachers' beliefs of the development of emotion regulation in school contexts]. In Schmitt, A., Sterdt, E. \& Fischer, L. (Hrsg.), Empirisches Arbeiten in der Frühpädagogik im Kontext eines evidenzbasierten Ansatzes - ein Tagungsbericht (47-58). Köln, Kronach: Carl Link.

\section{Conference contributions}

Schlesier, J. (2019). Teacher-student-interactions in situations with primary school children's anxiety. European Association for Research on Learning and Instruction (EARLI Conference), 12.08.-16.08.2019, RWTH Aachen (Single Paper).

Wagener, U., Schlesier, J., \& Moschner, B. (2019). Coherence in teacher education - a conceptual analysis and clarification of a comprehensive term. European Association for Research on Learning and Instruction (EARLI Conference), 12.08.-16.08.2019, RWTH Aachen (Poster).

Schlesier, J. (2018). Konzepte der Lehrer-Schüler-Interaktion: Eine qualitative Interviewstudie mit Grundschullehrkräften. Conference of the "Arbeitsgruppe für Empirische Pädagogische Forschung (AEPF)", 24.09.-26.09.2018, Leuphana University Lüneburg (Poster).

Schlesier, J., Roden, I., \& Moschner, B. (2018). Teachers' beliefs about the emotion regulation of boredom and anger in primary school children. EARLI Sig 5 Conference (Learning and Development in Early Childhood 2018), 29.08.-31.08.2018, Free University Berlin, Germany (Poster). [Nominated for Poster Award]

Roden, I., Mansholt, S., Schlesier, J., \& Kreutz, G. (2018). Effects of music and math training on mathematical and working memory performances. EARLI Sig 5 Conference (Learning and Development in Early Childhood 2018), 29.08.-31.08.2018, Free University Berlin, Germany (Poster). [Nominated for Poster Award]. 
Schlesier, J., Roden, I., \& Moschner, B. (2017). Emotion regulation in primary school children: a systematic review. Conference of the European Association for Research on Learning and Instruction (EARLI Conference), 29.08.-02.09.2017, Tampere, Finland (Single Paper).

Moschner, B., Schlesier, J., Wagener, U., \& Reimer, M. (2017). Student teachers' beliefs of an ideal teacher training at the university. European Association for Research on Learning and Instruction (EARLI Conference), 29.08.-02.09.2017, Tampere, Finland (Single Paper).

Schlesier, J. (2017). Teachers' beliefs about children's emotion regulation in the context of elementary schools. European Association for Research on Learning and Instruction (EARLI Pre-Conference), 27.08.28.08.2017, Tampere Finland (Poster).

Schlesier, J., Moschner, B., \& Grube, D. (2021). Lehrkraft-Schulkind-Interaktion während der Präsenzphase zwischen zwei Lockdowns: Eine Mehrebenenanalyse [Teacher-student-interactions during the attendance phase between two lockdowns: A multilevel analysis]. digiGEBF, Corona und Bildung, 22./23.04.2021 (Single Paper). 